\title{
N Alpha Methyl Histamine Versus Propranolol in Migraine Prophylaxis
}

\author{
R.O. Millán-Guerrero, R. Isais-Millán, B. Guzmán-Chávez, G. Castillo-Varela
}

\begin{abstract}
Objectives: To compare the efficacy and tolerability of the subcutaneous administration of N alpha methyl histamine versus oral propranolol in the treatment of migraine prophylaxis. Background: $\mathrm{N}$ alpha methyl histamine has a selective affinity for $\mathrm{H} 3$ receptors and could constitute a new therapeutic drug in migraine prophylaxis. Methods: Sixty patients with migraine were selected and enrolled in a 12-week double-blind controlled clinical trial to evaluate the efficacy of subcutaneous administration of $\mathrm{N}$-alpha methyl histamine ( 1 to 3 ug twice a week ) $\mathrm{n}=30$, compared to administration of $120 \mathrm{mg} /$ day of oral propranolol $\mathrm{n}=30$. The variables were: headache intensity, frequency of attacks, duration of migraine attacks and analgesic intake. Results: Fifty five patients completed the study. The data collected during the 4th week of treatment revealed that $\mathrm{N}$ alpha methyl histamine and propranolol caused a significantly $(\mathrm{p}<0.01)$ greater reduction between the basal values and final values of every variable studied. Conclusions: Both $\mathrm{N}$ alpha methyl histamine and propranolol are similarly effective in reducing or eliminating the headache in migraine prophylaxis. Low doses of $\mathrm{N}$-alpha methyl histamine injected subcutaneously may represent a novel and effective therapeutic alternative in migraine patients and may lay the clinical and pharmacological groundwork for the use of $\mathrm{H} 3$ receptor agonist in migraine prophylaxis.
\end{abstract}

RÉSUMÉ: N-alpha-méthyl-histamine comparée au propranolol dans la prophylaxie de la migraine. Objectifs : Le but de l'étude était de comparer l'efficacité et la tolérabilité de la N-alpha-méthyl-histamine par voie sous-cutanée à celle du propranolol par voie orale administrés en prophylaxie de la migraine. Contexte : La N-alpha-méthyl-histamine a une affinité sélective pour les récepteurs $\mathrm{H} 3$ et pourrait constituer un nouveau moyen de prévention de la migraine. Méthode : Soixante patients atteints de migraine ont été choisis et recrutés pour participer à un essai clinique contrôlé, à double insu, de 12 semaines afin d'évaluer l'efficacité de l'administration de $\mathrm{N}$-alpha-méthyl-histamine par voie sous-cutanée (1 à $3 \mu \mathrm{g}$ deux fois par semaine) $\mathrm{n}=30$, comparée à l'administration de $120 \mathrm{mg}$ de propranolol par jour $\mathrm{n}=30$. Les variables étudiées étaient l'intensité de la céphalée, la fréquence des crises de migraine, leur durée et les analgésiques utilisés. Résultats : Cinquante-cinq patients ont complété l'étude. Les données recueillies au cours de la 4e semaine de traitement ont montré que la $\mathrm{N}$-alpha-méthyl-histamine et le propranolol provoquaient une diminution significativement plus importante $(\mathrm{p}<0,01)$ par rapport aux valeurs de bases de toutes les variables étudiées. Conclusions : La N-alpha-méthyl-histamine et le propranolol sont aussi efficaces l'un que l'autre pour diminuer ou éliminer la céphalée en prophylaxie de la migraine. La N-alpha-méthyl-histamine par voie souscutanée à petites doses pourrait constituer un traitement alternatif nouveau et efficace chez les patients migraineux et établir les bases cliniques et pharmacologiques de l'utilisation d'un agoniste H3 en prophylaxie de la migraine.

Can J Neurol Sci. 2014; 41: 233-238

Migraine affects approximately $10 \%$ to $14.7 \%$ of the general population and $11 \%$ for lifetime migraine based on both the first edition of the International Classification of Headache Disorders (ICHD-I ${ }^{1}$ and second edition of the International Classification of Headache Disorders (ICHD-II $)^{2}$ definitions of migraine and it is two to three times more common in women than in $\mathrm{men}^{3,4}$. Many types of drugs are available for clinical use for the prevention of migraine, including $\beta$-blockers, antidepressants, antiepileptic agents, and calcium channel blockers, which have demonstrated efficacy in $70 \%$ of cases; nonetheless there is up to a $10 \%$ to $30 \%$ therapeutic failure rate, with persistent periodic migraine attacks, resulting in an elevated analgesic consumption and a significant deterioration in quality of life $\mathrm{e}^{5-8}$. Currently, few of the drugs employed in migraine prophylaxis act on specific mechanisms of the migraine pathophysiology ${ }^{9}$. The cause and pathophysiology of migraine are not well understood. There seems to be a relationship between brain metabolism and cerebrovascular dysfunction, which activates pain pathways that cause a series of events ending in neurogenic inflammation ${ }^{10,11}$, an important component in migraine that is perhaps genetically determined. In 1991 we carried out the first study ${ }^{12}$ providing evidence of the beneficial effect of histamine in migraine prophylaxis and of the histamine metabolite, $\mathrm{N}$ alpha methyl histamine, which possesses a greater affinity for $\mathrm{H} 3$ receptors ${ }^{13,14}$. In our clinical open study, Phase II and Phase III, we demonstrated that $\mathrm{N}$ alpha methyl histamine, at a dose ranging from 1 to $3 \mathrm{ug}$, has therapeutic potential in migraine prophylaxis. It induced significant relief from migraine symptoms, with no secondary effects; interestingly ${ }^{15,16} \mathrm{~N}$ alpha

\footnotetext{
From the Unidad de Investigación en Epidemiología Clínica (ROMG, GCV), Department of Neurology, Instituto Mexicano del Seguro Social, Colima, Col; Departamento de Anestesiología (RIM, BGC), Hospital de Especialidades Médicas, Centro Médico Nacional, La Raza, IMSS, México.

Received June 20, 2013. Final Revisions Submitted September 12, 2013. Correspondence to: Rebeca O. Millán Guerrero, J. Jesús Ponce No 538, Lomas de Circunvalación CP 28010, Colima, Col, México. Email: millanrebeca@ hotmail.com.
} 
methyl histamine could constitute a new therapeutic drug in migraine prophylaxis, that improves quality of life for migraine patients who do not respond (30-40\%) to the drugs used today; It could lay the clinical and pharmacological groundwork for the use of $\mathrm{H} 3$ agonists in migraine prophylaxis: and, finally; could help obtain a drug that acts upon specific mechanisms of pathophysiologic processes related to migraine. The aim of this study is to evaluate the therapeutic potential in migraine prophylaxis of subcutaneous administration of $\mathrm{N}$ alpha methyl histamine compared with oral administration of $\beta$-blockers (propranolol) ${ }^{17}$ in a clinical trial.

\section{Methods}

Sixty patients with migraine with or without aura were selected using the criteria of the International Headache Society ${ }^{1,2}$ and enrolled in a 12 -week double-blind controlled clinical trial to evaluate the efficacy of subcutaneous administration of $\mathrm{N}$ alpha methyl histamine (1 to $3 \mathrm{ug}$ twice a week ) $n=30$, compared to administration of $120 \mathrm{mg} /$ day of oral propranolol $n=30$. The selected patients hailed from multiple physicians and neurologists and their diagnoses were independently confirmed by a second member of the research team ${ }^{18}$. The trial procedure was explained to them and they were invited to take part in the study. All participants signed a letter of consent in accordance with the Helsinki statement and ethics committee of HGZ No 1 IMSS Colima, Colima, México. The patients were male or female adults between the ages of 18 and 65 years, all having a history of migraine for several years, with no additional neurological or cardiovascular pathologies; pregnant women, patients suffering from daily headaches and patients whose radiological tests, including computer-assisted tomography, revealed any pathology, were excluded from the study. Selected patients underwent a one-month period of prophylactic agent washout, during which headache frequency was monitored (Figure 1 flow diagram). They were then divided into two groups for treatment in randomized blocks of three ${ }^{19}$, double-blind fashion: the $\mathrm{N}$ alpha methyl histamine study group $(n=30)$ and the propranolol group $(n=30)$. This randomization was carried out by a research collaborator who throughout the duration of the study had no contact with the patients and prepared vials containing either $10 \mathrm{ug} / \mathrm{ml}$ subcutaneous $\mathrm{N}$ alpha methyl histamine or oral placebo; and $120 \mathrm{mg}$ oral propranolol or subcutaneous placebo (Evan's solution= phenol $0.4 \%$, isotonic sodium chloride). The vials were numbered and were identical in appearance, which allowed the blinding to be effective since neither the patients nor the physicians were able to identify the vehicle or active drug. The treatment consisted of subcutaneous (posterior region of the upper arm) administration of $\mathrm{N}$ alpha methyl histamine (10 ug/ ml in Evan's solution) 1 to 3 ug. twice a week. The regimen began with the administration of $0.1 \mathrm{ml}$ volume of either subcutaneous $\mathrm{N}$ alpha methyl histamine or placebo, which was consecutively increased (by 0.1 $\mathrm{ml}$ ) halting the increase at $0.3 \mathrm{ml}$. Continued repetition of this protocol (starting again with $0.1 \mathrm{ml}$ volume administration) and $120 \mathrm{mg}$ propranolol (40 mg/d x3) or subcutaneous placebo twice a week was carried out for a period of twelve weeks. During treatment, patients were allowed to take $500 \mathrm{mg}$ acetaminophen tablets if they had moderate to severe headache with an intensity value of 2 on a scale of 1 to 3 , and lasting for more than eight

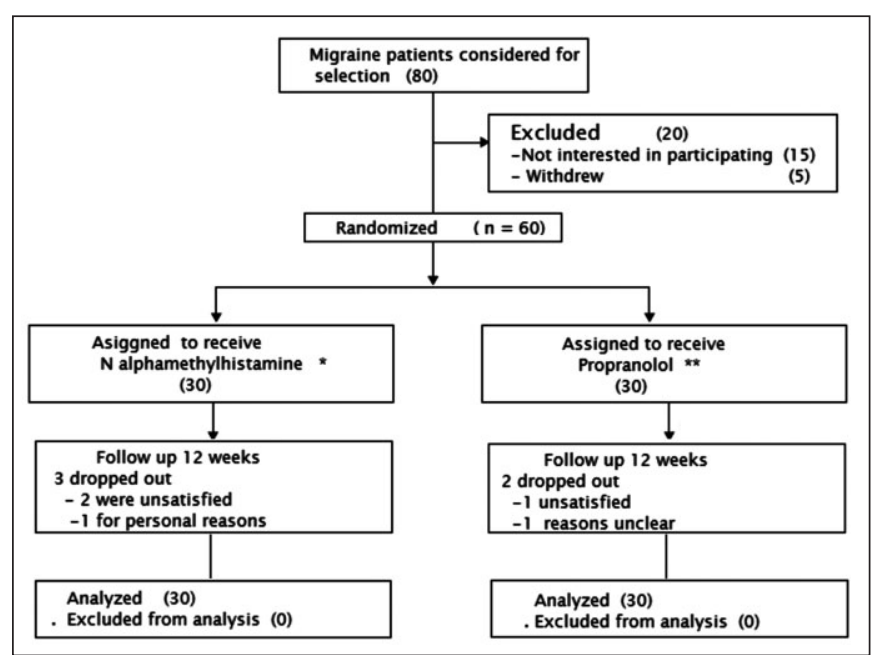

Figure 1: Flow of participants through the trial Consort diagram; * group 1 subcutaneous $N$ alpha methyl histamine or oral placebo; ** group $2120 \mathrm{mg}$ oral propranolol or subcutaneous placebo

hours (hrs). The variables studied ${ }^{20}$ were: 1 ) headache frequency, measured by number of attacks per month; 2) intensity of pain (scale from 1 to 3 ); 3) duration of pain, measured by hours of headache per attack; 4) intake of rescue analgesics, measured by the number of acetaminophen tablets $(500 \mathrm{mg})$ taken per month. Values for the parameters studied were collected over a period of four weeks before initiation of treatment (baseline), and efficacy and safety assessments were carried out every 30 days for a period of twelve weeks. Patients were instructed to keep a daily record of events. The relationship between an adverse event and the study treatment was assessed by the investigator as none, possible, probable, or definite. Patients who abandoned the study were still taken into account in the final analysis.

Statistical Analysis: Average descriptive statistics and standard deviations were applied to obtained data. The Wilcoxon rank-sum test was used to assess the statistical significance of differences between treatment groups in baseline characteristics (age, years since onset, age at onset), during the aforementioned weeks of treatment it was performed using a Mann-Whitney U rank sum test. In order to analyze the temporal course of each treatment (for each variable studied), a Friedman repeated measures analysis of variance (ANOVA) on ranks test was used to evaluate the statistical significance of differences between basal values and values found for the 4th and 12th weeks of treatment. With an alpha level of 0.05 , the trial was designed to have a statistical power of 80 percent, $\mathrm{p}<0.05$ was considered significant ${ }^{21}$. Data statistical analysis was carried out using the Statistical Package for Social Sciences program (SPSS 10.0). The study was approved by the Ethical and Scientific Committee of our hospital and the Australian New Zealand Clinical Trials Registry (ANZCTR). ACTRN12610000126011.

\section{RESULTS}

From the total of 60 patients enrolled and randomized into the two groups ( $\mathrm{N}$ alpha methyl histamine $\mathrm{n}=30$; propranolol $\mathrm{n}=30$ ), 27 in the $\mathrm{N}$ alpha methyl group and 28 in the propranolol group 


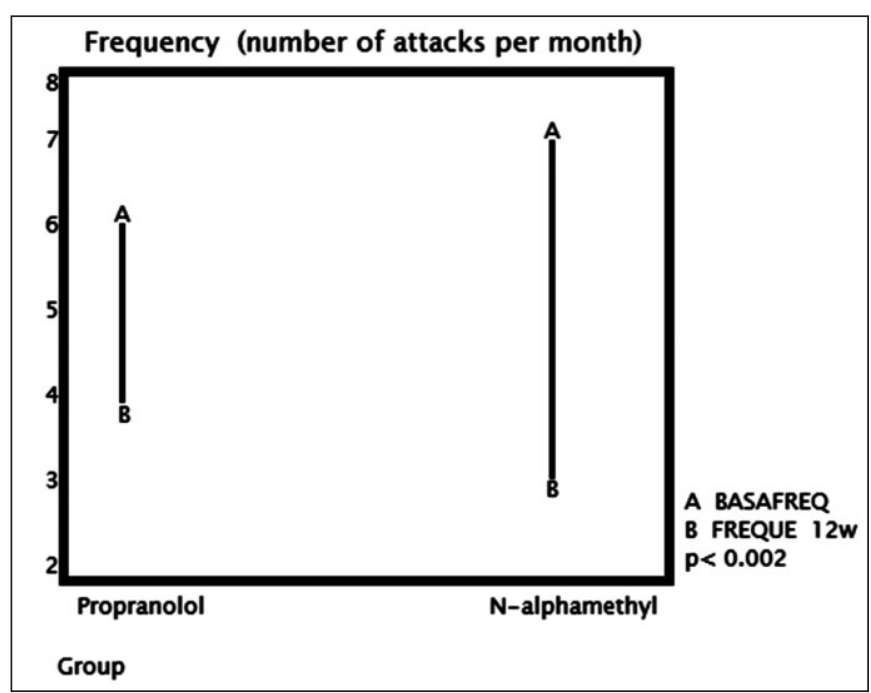

Figure 2: Effects induced (in 60 patients with recurrent migraine) by the subcutaneous administration (twice a week, during 12 weeks) of $N$ alpha methyl histamine $(n=30)$ and oral propranolol $(n=30)$ on the frequency. Data correspond to mean values (plus SEM) obtained during a 4-week period prior to initiation of treatment (Basal), and 12 weeks of treatment.

completed the study. A total of $90 \%$ of the patients were female (26 female: 4 male in the $\mathrm{N}$ alpha methyl histamine group and 28 female/ 2 male in the propranolol group). mean age was of 35 years \pm 11.7 (range 18 to 60 ). Headache duration was $12 \pm 9.3$ years and frequency of migraine attacks was 5.12 (95\% IC 1.23 to 1.89) per month with or without aura. The treatment groups were similar at baseline based on demographic and clinical

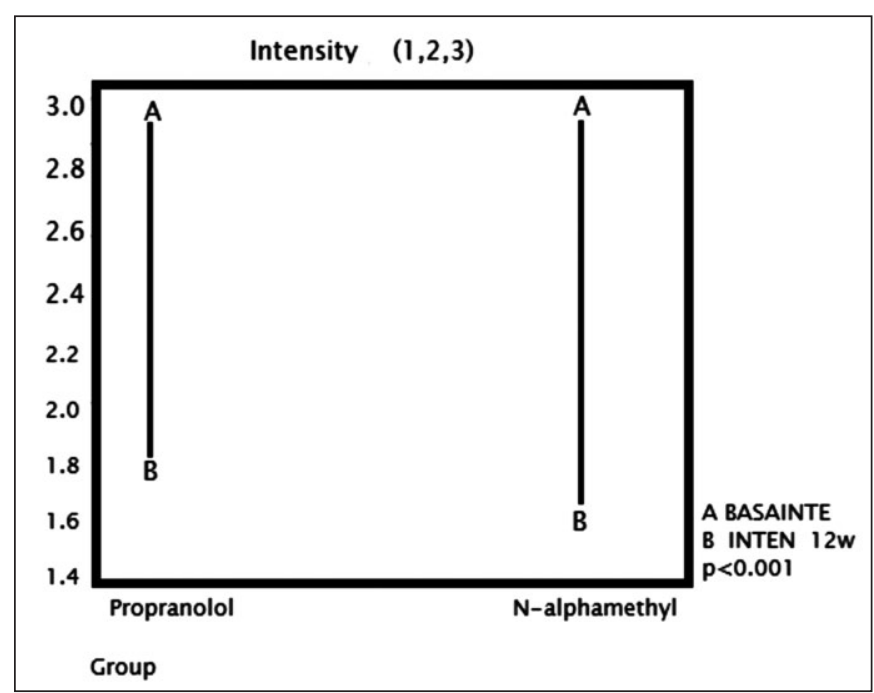

Figure 3: Effects induced (in 60 patients with recurrent migraine) by the subcutaneous administration (twice a week, during 12 weeks) of $N$ alpha methyl histamine $(n=30)$ and oral propranolol $(n=30)$ on the intensity. Data correspond to mean values (plus SEM) obtained during a 4-week period prior to initiation of treatment (Basal), and 12 weeks of treatment.

characteristics (Table) for all variables studied. The statistical analysis of data collected showed no significant differences between the baseline values obtained for the $\mathrm{N}$ alpha methyl histamine and the propranolol treatment groups $(\mathrm{P}>0.05)$.

We compared the response of one group to its baseline and the differential response of one group to the other. Analysis of the temporal course of events showed that by the beginning of

Table: General and clinical characteristics of patients

\begin{tabular}{c|c|c|c}
\hline FEATURE & $\begin{array}{c}\text { N-alpha methyl Histamine } \\
(\mathrm{n}=30)\end{array}$ & $\begin{array}{c}\text { Propranolol } \\
(\mathrm{n}=30)\end{array}$ & $\mathrm{p}$ \\
\hline Age years (mean \pm$)$ & $35( \pm 15)$ & $33( \pm 10)$ & 2 \\
\hline Male & 4 & 28 & \\
\hline Female & $12( \pm 9)$ & $16( \pm 10)$ & \\
\hline $\begin{array}{c}\text { Migraine type } \\
\text { with aura } \\
\text { without aura }\end{array}$ & 10 & 21 & \\
\hline $\begin{array}{c}\text { Age at onset (mean years } \\
\text { Years migraine (mean) }\end{array}$ & 20 & $17( \pm 8.8)$ & \\
\hline $\begin{array}{c}\text { Frequency of headaches per 30-day periods at baseline. } \\
\text { (mean score) }\end{array}$ & $7.0( \pm 1.1)$ & $6( \pm 1.1)$ & $\mathrm{P}<0.86$ \\
\hline Intensity of headache at baseline 1,2,3 & $2.9( \pm .2)$ & $2.9( \pm .1 .8)$ & $\mathrm{p}<0.69$ \\
\hline Duration of headache hours. (mean score) & $46( \pm 12)$ & $29( \pm 11)$ & $\mathrm{P}<0.02$ \\
\hline Tablets/mo of rescue. (mean score) & $25( \pm 9.4)$ & $29( \pm 8)$ & $\mathrm{P}<.0 .27$ \\
\hline
\end{tabular}

(before undergoing period washout of prophylactic agents) 
the 4th week, there was a significant decrease (with respect to basal values) in the magnitude of all parameters studied, as a result of the scheme followed for the administration of $\mathrm{N}$ alpha methyl histamine $(\mathrm{P}<0.001)$ or propranolol $(\mathrm{P}<0.001)$. The same was found for values at the 8 th, and 12 th weeks of treatment. (Figure 2-5)

The rate of response to $\mathrm{N}$ alpha methyl histamine (Figure 2) was $62 \%$ (17 of 27 patients) reported a $67 \%$ reduction in headache frequency $(\mathrm{P}<0.001)$ (mean, $7.095 \% \mathrm{CI} 1.2$ to 1.8 attacks per month before treatment vs $2.895 \% \mathrm{CI} 1$ to 1.2 attacks per month after treatment) number needed to treat (NNT) 4 , and the rate of response to propranolol was 60 percent (17 of 28 patients), reported a $52 \%$ reduction $(\mathrm{P}<0.001)$ (mean 6.0 $95 \%$ CI .6 to 1.6 attacks per month before treatment vs $4.095 \%$ CI .6 to 1.1 attacks per month after treatment) NNT 4.

For pain intensity (Figure 3) 70\% (19 of 27 patients) receiving $\mathrm{N}$ alpha methyl histamine reported a $47 \%$ reduction in headache intensity $(\mathrm{P}<0.001)$ (mean, $2.995 \%$ CI 1.2 to .2 before treatment vs $1.695 \%$ CI .5 to .2 after treatment) NNT 3; whereas 60 percent (17 of 28 patients) receiving propranolol reported a $52 \%$ reduction in intensity of pain $(\mathrm{P}<0.001)$ (mean $2.995 \% \mathrm{CI}$ 1.8 to .5 before treatment vs $1.8095 \% \mathrm{CI} .4$ to .3 after treatment) NNT 5.

Comparison between both groups (Figure 4) revealed a significant reduction in duration of migraine attacks: The rate of response to $\mathrm{N}$ alpha methyl histamine was $62 \%$ (17 of 27 patients), with a $67 \%$ reduction in duration of migraine attacks $\mathrm{P}<0.001$ (mean, $4695 \%$ CI 12.5 to 6.4 hours of headache per attack before treatment vs $18.8095 \%$ CI 9.6 to 9.2 hours of headache per attack after treatment) (NNT 4); and the rate of response to propranolol was $64 \%$ (18 of 28 patients), with a $71 \%$ reduction $\mathrm{P}<0.001$ (mean $2995 \%$ CI 11.1 to 6.5 hours of

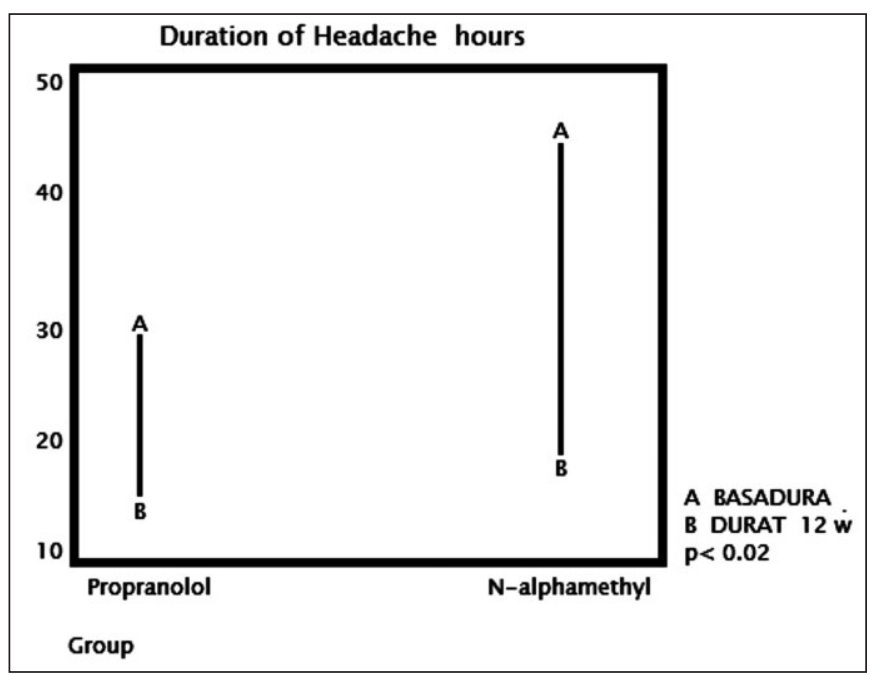

Figure 4: Effects induced (in 60 patients with recurrent migraine) by the subcutaneous administration (twice a week, during 12 weeks) of $N$ alpha methyl histamine $(n=30)$ and oral propranolol $(n=30)$ on the duration of migraine attacks. Data correspond to mean values (plus SEM) obtained during a 4-week period prior to initiation of treatment (Basal), and 12 weeks of treatment. headache per attack before treatment vs $14.8795 \%$ CI 8.2 to 9.4 hours of headache per attack after treatment (NNT 3.5).

In relation to rescue medication (Figure 5) $59 \%$ of patients receiving $\mathrm{N}$ alpha methyl histamine (16 of 27) reported a $47 \%$ reduction in the number of tablets ingested $\mathrm{P}<0.001$ (mean, 25 95\% CI 12.1 to 7.2 acetaminophen tablets per month before treatment vs $11.395 \%$ CI 3.2 to 10.1 acetaminophen tablets per month after treatment) (NNT.5), whereas $64 \%$ of patients (18 of $28)$ receiving propranolol reported a $70 \%$ reduction $(\mathrm{P}<0.001)$ (mean $29.95 \%$ CI 7.5 to 4.5 acetaminophen tablets per month before treatment vs $15.4795 \%$ CI 5.2 to 4 acetaminophen tablets per month after treatment (NNT 4).

Ten percent $(3 / 30)$ of patients in the $\mathrm{N}$ alpha methyl histamine group withdrew without adverse events, because they were not satisfied with the speed of the results even though they did not present any side effects; some transitory burning and itching at the injection site was reported, but it was not significant enough to impede the blinding of the assay or the planned order of events. There were no modifications in arterial blood pressure or cardiac frequency in either group for the duration of the study, nor were there any alterations in the laboratory analyses performed at the beginning and end of the study. After 12 weeks of treatment, the effects of $\mathrm{N}$ alpha methyl histamine and propranolol remained identical to the values found at the 8th week.

\section{DISCUSSION}

It has been demonstrated that high concentrations of histamine activate $\mathrm{H} 1$ receptors, producing vasodilatation and release of nitric oxide which conduces to neurogenic edema and is responsible for the acute phase of migraine 22,23 ; however, the results obtained in this and in previous placebo-controlled studies $^{12}$ show that histamine and the $\mathrm{N}$ alpha methyl histamine

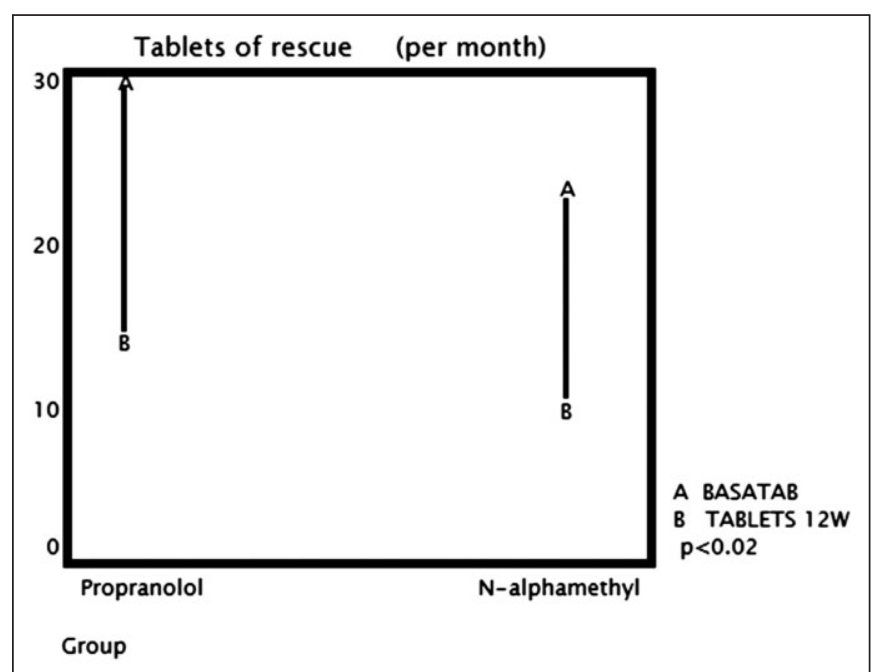

Figure 5: Effects induced (in 60 patients with recurrent migraine) by the subcutaneous administration (twice a week, during 12 weeks) of $N$ alpha methyl histamine $(n=30)$ and oral propranolol $(n=30)$ on the consumption of $500 \mathrm{mg}$ acetaminophen tablets used as rescue medication during headache. Data correspond to mean values (plus SEM) obtained during a 4-week period prior to initiation of treatment (Basal), and 12 weeks of treatment. 
at low concentrations are safe drugs with therapeutic potential in migraine prophylaxis, exercising specific mechanisms on pathophysiological processes involved in this disease. In migraine pathophysiology, the antidromic stimulation of trigeminal nerve endings induces the release of substance $\mathrm{P}$ and other neuromodulatory peptides, which in turn stimulate the release of histamine from mast cells. In meningeal blood vessels, activation of H1-receptors (H1-R) by high concentrations of histamine results in vasodilatation and plasma protein extravasation, causing vasogenic-neurogenic inflammation ${ }^{24}$. Under conditions of homeostasis, low concentrations of histamine activate the $\mathrm{H} 3$ receptors of $\mathrm{C}$ fiber nerve endings and mast cells and block the exit of neuropeptides, among them histamine itself, by negative feedback ${ }^{13,25,26}$ circuit between $\mathrm{C}$ fiber nerve endings and mast cells, which control neurogenic inflammation ${ }^{10,27}$. Histamine $\mathrm{H} 3$ receptors are autoreceptors that negatively regulate the release of histamine and other neurotransmitters and are believed to play a variety of physiological roles, including the regulation of feeding, arousal, cognition, pain, and endocrine systems ${ }^{25,28-30}$.

Two histaminergic $\mathrm{H} 3$ receptors have been identified, which differ in their sensitivity to guanidile-nucleotide inhibition and are differentially activated by $\mathrm{R}$ alpha methyl histamine $(\mathrm{Kd}=12 \mathrm{nM})$ and by $\mathrm{N}$ alpha methyl histamine $(\mathrm{Kd}=0.36 \mathrm{nM})$; the first crosses the hematoencephalitic barrier easily, while the second does not ${ }^{28}$. The histamine metabolite $\mathrm{N}$ alpha methyl histamine possesses a greater affinity for $\mathrm{H} 3$ receptors. In our clinical study, Phase II and Phase III, we demonstrated that N alpha methyl histamine at doses from 1 to $3 \mathrm{ug}$, has therapeutic potential in migraine prophylaxis, inducing significant relief from migraine symptoms with no secondary effects; interestingly, we obtained an effective response at a low dose (1 to $3 \mathrm{ug}$ ), with a significant reduction in headache frequency, intensity, duration, and analgesic intake; however, when we employed doses greater than $4 \mathrm{ug}$, headache developed ${ }^{15,16}$.

Our data reveal that the administration of $\mathrm{N}$ alpha methyl histamine, at low doses (1-3 ug), induces significant relief from migraine symptoms without complications. After the clinical trial was over, some of the patients treated with $\mathrm{N}$ alpha methyl histamine remained asymptomatic, without headache crises, while others showed significant relief from migraine symptoms for a period ranging from six to twelve months. A cross-over study was not carried out, due to the fact that the use of drugs having a prolonged therapeutic effect does not lend itself well to such a study. Altogether, the results obtained in this study show that $\mathrm{N}$ alpha methyl histamine is a safe drug with therapeutic potential in migraine prophylaxis.

This randomized study demonstrated that both $\mathrm{N}$ alpha methyl histamine and propranolol are similarly effective, and well tolerated, in reducing or eliminating the headache in migraine prophylaxis. Low doses of $\mathrm{N}$ alpha methyl histamine injected subcutaneously may represent a novel and effective therapeutic alternative in patients presenting with recurrent migraine who do not respond to beta adrenergic or calcium channel blockers or patients over 60 years-of-age who have hypotension or cardiac rhythm alterations and in whom the usual drugs are contraindicated, or in patients who have developed secondary gastritis and cannot tolerate further oral drug therapy. Twice-weekly, subcutaneous injection of histamine or $\mathrm{N}$ alpha methyl histamine in low concentrations has been accepted in our practice by patients who previously had not been satisfied with the daily administration of other medications, and may lay the clinical and pharmacological groundwork for the use of $\mathrm{H} 3$ agonist in migraine prophylaxis.

A better understanding of migraine pathophysiology along with the discovery of novel molecular targets has led to a growing number of upcoming therapeutic proposals ${ }^{31-33}$. The possibility of better modulating the imbalance between central neurotransmitters that occurs with migraine has created an exciting search for new pharmacologic sites. Neuromodulators for the prevention of multiple mechanisms related to migraine are already available ${ }^{34-36}$.

\section{ACKNOWLEDGEMENTS}

The authors thank all the patients who participated in the study.

\section{REFERENCES}

1. Classification and diagnostic criteria for headache disorders, cranial neuralgias and facial pain. Headache Classification Committee of the International Headache Society. Cephalalgia. 1988;8 (Suppl. 7):1-96.

2. International classification of headache disorders-II. Cephalalgia. 2004;24(Supp 1):1-52.

3. Lipton RB, Bigal ME. Ten lessons on the epidemiology of migraine. Headache. 2007;47(Suppl. 1):S2-9.

4. Linde M, Gustavsson A, Stovner LJ, et al. The cost of headache disorders in Europe: the Eurolight project. Eur J Neurol. 2012; 19:703-11.

5. Lipton RB, Bigal ME, Diamond M, et al. Migraine prevalence, disease burden, and the need for preventive therapy. Neurology. 2007;68:343-9.

6. Holland S, Silberstein SD, Freitag F, et al. Evidence-based guideline update: NSAIDs and other complementary treatments for episodic migraine prevention in adults. Report of the Quality Standards Subcommittee of the American Academy of Neurology and the American Headache Society. Neurology. 2012;78:1346-53.

7. Buchanan TM, Ramadan M. Prophylactic pharmacotherapy for migraine headaches. Semin Neurol. 2006;26:188-98.

8. Lohman J, Van der Kuy-de Ree M. Patterns of specific antimigraine drug use-a study based on the records of 18 community pharmacies. Cephalalgia. 2005;25:214-18.

9. Shields KG, Goadsby PJ. Propranolol modulates trigeminovascular responses in thalamic ventroposteromedial nucleus: a role in migraine? Brain. 2005;128:86-97.

10. Sanchez-Del-Rio M, Reuter U, Moskowitz MA. New insights into migraine pathophysiology. Curr Opin Neurol. 2006; 19:294-8.

11. Moskowitz MA. The neurobiology of vascular head pain. Ann Neurol. 1984;16:157-68.

12. Millán GR, Isais CM, Antonio OA, et al. Histamine as a therapeutic alternative in migraine prophylaxis: a randomized, placebocontrolled, double-blind study. Headache. 1999;39:576-80.

13. Ishikawa $\mathrm{S}$, Speralakis N. A novel class H3 of histamine receptors on perivascular nerve terminals. Nature. 1987;327:158-60.

14. Göthert M, Garbarg M, Hey J A, et al. New aspects of the role of histamine in cardiovascular function: Identification, characterization, and potential pathophysiological importance of H3 receptors. Can J Pharmacol. 1995;73:558-64.

15. Millán GR, Pineda LA, Trujillo HB, et al. N alpha methyl histamine safety and efficacy in migraine prophylaxis: Phase I and Phase II studies. Headache. 2003;43:389-94.

16. Millán-Guerrero RO, Isais- Millán R, Trujillo Hernández B, et al. N alpha methyl histamine safety and efficacy in migraine prophylaxis: Phase III study. Can J Neurol Sci. 2006;33:195-9.

17. Silberstein SD, Holland S, Freitag F, et al. Evidence-based guideline update: pharmacologic treatment for episodic migraine prevention in adults: Report of the Quality Standards 
Subcommittee of the American Academy of Neurology and the American Headache Society. Neurology. 2012;78:1337-45.

18. International Classification of Headache Disorders, Olesen J. International Classification of Headache Disorders, Second Edition (ICHD-2): current status and future revisions. Cephalalgia. 2006;26:1409-10.

19. Lipchik GL. Nicholson RA, Penzien DB. Allocation of patients to conditions in headache clinical trials: randomization, stratification and treatment matching. Headache. 2005;45: 419-28.

20. International Headache Society committee on clinical trials in migraine. Guidelines for controlled trials of drugs in migraine. Cephalalgia. 1991;11:1-12.

21. Hulley SB, Gove S, Cummings SR. Elección de los individuos que participarán en el estudio: especificación y muestreo. En: Hulley SB, Cummings SR, editors. Diseño de la Investigación Clínica. España: Harcourt Brace; 1997. p.21-55.

22. Lassen LH. Thomsen LL. Olesen J. Histamine induce migraine via the $\mathrm{H} 1$ receptor. Support for the NO hypothesis of migraine. Neuroreport. 1995;6:1475-9.

23. Thomsen LL, Olesen JB. Nitric oxide in primary headache. Curr Opin Neurol. 2001;14:315-21.

24. Peroutka SJ. Neurogenic inflammation and migraine: Implications for therapeutics. Mol Interv. 2005;5:304-11.

25. Arrang JM, Garbarg M, Schwartz JC. Auto-inhibition of brain histamine release mediated by a novel class (H3) of histamine receptor. Nature. 1983;302:832-7.

26. Arrang J-M, Garbarg M, Schwartz J-C. Autoinhibition of histamine synthesis mediated by presynaptic H3-receptors. Neuroscience. $1987 ; 23: 149-57$
27. Waeber $\mathrm{CH}$, Moskowitz MA. Migraine as an inflammatory disorder. Neurology. 2005;64(Suppl 2); S9-15.

28. West RE, Zweig A, Shih N-Y, et al. Identification of two H3histamine receptor subtypes. Mol Pharmacol. 1990;38:610-13.

29. Dimitriadou V, Rouleau A, Dam Trung, et al. Functional relationship between mast cells and $\mathrm{C}$-sensitive nerve fibers evidenced by histamine $\mathrm{H} 3$-receptor modulation in rat lung and spleen. Clin Sci. 1994;87:151-63.

30. Tokita S, Takahashi K, Kotani H. Recent advances in molecular pharmacology of the histamine systems: physiology and pharmacology of histamine $\mathrm{h} 3$ receptor: roles in feeding regulation and therapeutic potential for metabolic disorders. J Pharmacol Sci. 2006;101:12-18.

31. Olesen J, Diener HC, Husstedt IW, et al. Calcitonin gene-related peptide receptor antagonist BIBN $4096 \mathrm{BS}$ for the acute treatment of migraine. New Engl J Med. 2004;350:1104-10.

32. Goadsby PJ. Recent advances in the diagnosis and management of migraine. Brit Med J. 2006;332:25-9.

33. Loder E. Prophylaxis: headaches that never happen. Headache. 2008;48:694-6.

34. Marmura MJ, Silbertein S. Current understanding and treatment of headache disorders. Neurol Clin Pract. 2011;76 (Suppl 2):S31-6.

35. Durham PL, Masterson CG. Two mechanisms involved in trigeminal CGRP release: implications for migraine treatment. Headache. 2013;53:67-80.

36. Sieberg CHB, Huguet A, Von Baeyer CL, et al. Psychological interventions for headache in children and adolescents. Can J Neurol Sci. 2012;39:26-34. 